\title{
RELATION BETWEEN TWO SCORING PROCEDURES TO ASSESS AUDITORY MEMORY AND SEQUENCING ABILITIES
}

\author{
Ramya Vaidyanath, Asha Yathiraj
}

Department of Audiology, All India Institute of Speech and Hearing, Mysore, Karnataka, India

Corresponding author: Ramya Vaidyanath, Junior Research Fellow, Department of Audiology, All India Institute of Speech and Hearing, Mysore, Karnataka, India, e-mail: ramyavaidyanath@gmail.com

\begin{abstract}
Background: Tests to assess auditory memory are scored differently, but there is scanty information regarding the effect of the scoring procedure.

Material and method: The current retrospective study compared two scoring procedures for evaluating auditory memory in 189 children aged 5 to 11 years. One scoring procedure was the original memory technique used by Yathiraj and Vijayalaksh$\mathrm{mi}$. The other was a modification calculated using the same data obtained by Yathiraj and Vijayalakshmi. The original auditory memory and sequencing scoring procedure required the administration of the entire test, while the alternate scoring procedure, that calculated auditory memory and sequencing span, did not.
\end{abstract}

Results: A Pearson's correlation coefficient between the two scoring procedure was calculated. Both scoring procedures showed gradual improvement with age. A significant high correlation was found between the two scoring procedures when the age groups were combined.

Conclusions: Since the two scoring procedures provide similar information, it is recommended that, for individuals with relatively poor auditory memory and sequencing abilities, the span should be the choice of scoring. This would avoid a sense of failure when individuals are tested on the more difficult longer word-sequences. Additionally, it would make the test more time efficient. However, if subtle changes in performance across ages are to be determined, the original scoring procedure is recommended.

Keywords: auditory memory score $\bullet$ auditory sequencing score $\bullet$ auditory memory span $\bullet$ and auditory sequencing span

\section{RELACIÓN ENTRE DOS PROCEDIMIENTOS DE EVALUACIÓN DE MEMORIA AUDITIVA Y DE MEMORIZACIÓN DE SECUENCIAS}

\section{Resumen}

Fondo: Los análisis de la memoria auditiva utilizan diferentes formas de evaluación, sin embargo, falta la información respecto a los resultados de cada una de ellas

Materiales y métodos: En los estudios retrospectivos realizados se han comparado dos procedimientos de evaluación para examinar la memoria auditiva en 189 niños de 5 a 11 años. El primer procedimiento de valoración se basaba en el método de la memoria primaria, utilizada por Yathiraj y Vijayalakshmi. El segundo método ha sido modificado, pero aprovechando los mismos datos que los obtenidos por Yathiraj y Vijayalkshmi. Para el procedimiento de la evaluación de la memoria auditiva primaria y de la memorización de las secuencias fue necesario realizar ensayos completos, mientras estos no han sido necesarios en el caso del método alternativo, que valoraba el alcance de la memoria auditiva y de la memorización de las secuencias.

Resultados: Se ha definido el coeficiente de la correlación de Pearson entre dos procedimientos de evaluación. Ambos procedimientos de valoración mostraron una mejora gradual con la edad. Se ha demostrado una correlación especialmente elevada entre los procedimientos de evaluación cuando los grupos de edad fueron unidos.

Conclusiones: Dado que ambos procedimientos de evaluación proporcionan información similar, se recomienda que para las personas con la memoria auditiva y con la capacidad de memorizar secuencias relativamente malas, su alcance debería determinar la elección del procedimiento de evaluación. Esto permitiría evitar el sentimiento de fracaso que puede ocurrir cuando las personas están sujetas a las pruebas en base a unas secuencias de palabras difíciles y largas. Además, esto afectaría la eficacia de la prueba. Sin embargo, en el caso de evaluación de diferencias en los resultados de las personas de todas las edades, se recomienda el método tradicional de evaluación. 
Palabras clave: resultados de memoria auditiva $\bullet$ resultados de memorización de secuencias $\bullet$ alcance de la memoria auditiva - alcance de memorización de secuencias

\title{
СВЯЗЬ МЕЖДУ ДВУМЯ ПРОЦЕДУРАМИ ОЦЕНКИ СЛУХОВОЙ ПАМЯТИ И ЗАПОМИНАНИЯ ПОСЛЕДОВАТЕЛЬНОСТЕЙ
}

\section{Изложение}

Фон: Исследования слуховой памяти используют разные формы оценки, однако не хватает информации относительно результатов этих отдельных процедур.

\begin{abstract}
Материал и методы: Проведенные ретроспективные исследования сравнили две процедуры оценки с целью исследования слуховой памяти у 189 детей в возрасте от 5 до 11 лет. Первая процедура оценки заключалась в методе первичной памяти, использованной Ятхирай (Yathiraj) и Вияялакшми (Vijayalakshmi). Вторая была модифицирована, но с использованием этих самых данных, которые получили Ятхирай и Вияялакшми. Процедура оценки первичной слуховой памяти и запоминания последовательностей требовала проведения полных исследований, тогда как они не были необходимыми в случае альтернативного метода, который оценивал объем слуховой памяти и запоминания последовательностей.
\end{abstract}

Результаты: Определен коэффициент корреляции Пирсона между двумя процедурами оценки. Показано особенно высокую корреляцию между процедурами оценки, когда возрастные группы были объединены. Обе процедуры оценки показывали постепенное улучшение с возрастом пациентов.

Итоги: В связи с тем, что обе процедуры оценки предоставляют подобную информацию, рекомендуется, что для людей с относительно слабой слуховой памятью и умениями запоминать последовательности, их объем должен определять выбор процедуры оценки. Это уберегло бы от чувства поражения, которое может появиться в случае, когда люди становятся объектами исследований, которые проводятся на основании сложных и длинных последовательностей слов. Кроме того, это имело бы влияние на эффективность исследования. Однако, в случае исследования разниц в результатах людей разного возраста рекомендуется традиционный метод оценки.

Ключевые слова: результаты слуховой памяти • результаты запоминания последовательностей • объем слуховой памяти • объем запоминания последовательностей

\section{ZWIĄZEK POMIĘDZY DWIEMA PROCEDURAMI OCENY PAMIĘCI SŁUCHOWEJ I ZAPAMIĘTYWANIA SEKWENCJI}

\section{Streszczenie}

Tło: Badania pamięci słuchowej wykorzystują różne formy oceny, jednakże brakuje informacji odnoście wyników tych poszczególnych procedur.

Materiał i metody: Przeprowadzone badania retrospektywne porównywały dwie procedury oceny w celu zbadania pamięci słuchowej u 189 dzieci w wieku od 5 do 11 lat. Pierwsza procedura oceny polegała na metodzie pamięci pierwotnej używanej przez Yathiraj i Vijayalakshmi. Druga została zmodyfikowana ale przy korzystaniu z tych samych danych, które uzyskali Yathiraj i Vijayalakshmi. Procedura oceny pierwotnej pamięci słuchowej i zapamiętywania sekwencji wymagała przeprowadzenia pełnych badań, podczas gdy nie były one konieczne w przypadku alternatywnej metody, która oceniała zakres pamięci słuchowej i zapamiętywania sekwencji.

Wyniki: Określono współczynnik korelacji Pearsona pomiędzy dwiema procedurami oceny. Obie procedury oceny wykazywały stopniową poprawę wraz z wiekiem. Wykazano szczególnie wysoką korelację pomiędzy procedurami oceny gdy grupy wiekowe zostały połączone.

Wnioski: W związku z tym, że obie procedury oceny dostarczają podobne informacje, zaleca się, że dla osób z relatywnie słabą pamięcią słuchową i umiejętnościami zapamiętywania sekwencji, ich zakres powinien determinować wybór procedury oceny. Uchroniłoby to przed poczuciem porażki, które może się pojawić w przypadku, gdy osoby są poddawane badaniom w oparciu o trudne i długie sekwencje słów. Ponadto, wpłynęłoby to na efektywność badania. Jednakże, w przypadku badania różnic w wynikach osób w różnym wieku zaleca się tradycyjną metodę oceny.

Słowa kluczowe: wyniki pamięci słuchowej • wyniki zapamiętywania sekwencji • zakres pamięci słuchowej • zakres zapamiętywanych sekwencji 


\section{Background}

The link between memory and communication skills is undisputed [1-4]. The importance of assessing auditory memory has been demonstrated in research dealing with different communication problems. Auditory memory has been found to be compromised in children with auditory processing deficits $[5,6]$. Studies have also found that working memory abilities can predict learning/scholastic progress of children and reading comprehension [7-11]. In addition, evaluation of memory has been used by psychologists to determine intelligence [12], a factor known to have an impact on an individual's communication ability.

In acceptance of the link between auditory memory and communication, components of memory have been included in several tests or battery of tests that assess communication or auditory processing [2,13-17]. The memory skill assessed varies from test to test. Tests such as the 'Working memory test battery for children' [18] and the 'Automated working memory assessment battery' [19] have been designed to determine working memory. On the other hand, tests such as the 'Kannada auditory memory and sequencing test' [20] and the 'Revised auditory memory and sequencing test in Indian-English' [16] have focused on the evaluation of auditory memory and sequencing. The primary difference between the tests is in the scoring procedure. The use of span as a scoring procedure to assess memory was used as early as 1939 in two tests developed by Anderson [21]. This scoring procedure continues to be utilised in several other tests such as the 'Auditory memory span test' [22], the 'Working memory index of WISC-IV' [23], and the 'Working memory index of WAIS-IV' [24]. Memory span has been evaluated using a variety of stimuli such as digits $[18,19,23,24]$, word lists $[16,18,19,20,22]$, non-words $[18,19]$, letter-number sequences $[23,24]$, and recall of words within sentences $[18,19]$.

From the literature, it is evident that measurement of memory span has been used extensively in the course of evaluating auditory memory skills. This has been found to be effective while establishing working memory skills [25]. Evaluating auditory memory and sequencing using the procedure recommended by Yathiraj and Vijayalakshmi [20] is a more time-consuming technique that entails the presentation of all stimuli in the test. To determine the memory and sequencing scores using the procedure recommended by them, individuals are required to listen to the entire list, irrespective of whether they find the later part of the test difficult or not. Thus, unnecessary time is spent evaluating those with poor word memory abilities. Hence, this retrospective study was carried out with the aim of establishing an alternative scoring method for detecting memory problems in individuals. The study also aimed to determine the relation between the new memory scoring procedure with that originally used by Yathiraj and Vijayalakshmi.

\section{Material and methods}

\section{Participants}

The retrospective study involved reanalysing the raw data of the 'Kannada auditory memory and sequencing test'
Table 1. Number of tokens for each word sequence within the Kannada Auditory Memory and Sequencing Test

\begin{tabular}{cc}
\hline Word sequence & Number of tokens \\
\hline 3-word & 2 \\
\hline 4-word & 2 \\
\hline 5-word & 4 \\
\hline 6-word & 4 \\
\hline 7-word & 4 \\
\hline 8-word & 4 \\
\hline
\end{tabular}

developed by Yathiraj and Vijayalakshmi [20]. The original study evaluated 210 children with normal hearing ranging in age from 5 years to 11 years 11 months. The current study reanalysed the data of 189 of these children. The data of 21 children could not be reanalysed due to the manner in which the original data entry had been made. Yathiraj and Vijayalakshmi reported that the children had been screened to confirm the presence of normal hearing sensitivity using pure-tone and immittance audiometry. Raven's coloured progressive matrix was used to establish the presence of normal intelligence. The screening checklist for auditory processing $[26,27]$ was also administered to rule out the presence of any auditory processing disorder. The participants were divided into 7 age groups: children aged $5,6,7,8,9,10$, and 11 years.

\section{Procedure}

The four lists of the 'Kannada auditory memory and sequencing test' was administered on the children in a quiet room free from distractions. The stimuli were presented using a CD player through a loudspeaker kept at $0^{\circ}$ azimuth. Each list of the test had different inter-stimulus intervals between the test items $(250,500,750, \& 1000 \mathrm{~ms})$, with all lists having word sequences that increased in length. The lists had different inter-stimulus intervals since one of the aims of the original study by Yathiraj and Vijayalakshmi [20] was to determine its impact on memory and sequencing scores. Each list commenced with 3-word sequences and progressed to 4-, 5-, 6-, 7-, and 8-word sequences. The number of tokens (groups of words for a word-sequence) in each word-sequence varied. The 3-word and 4-word sequences had two tokens each and the remaining word sequences had 4 tokens each (Table 1). For example, Token 1 of the 3-word sequence contained the words /lari/, /sebu/, /t $\int a k u /$ and Token 2 contained /mant $\int a /$, /bekku/, /tuți/.

In the original scoring procedure of Yathiraj and Vijayalakshmi [20], a score of 1 was awarded for every word that was correctly recalled and an additional score of 1 given for a word recalled in the correct sequence. The memory and sequencing scores were calculated separately, with the maximum score for each being 118. In the current study, an alternative scoring procedure was utilised that involved not having to calculate the scores of the complete test for those individuals unable to repeat the longer word sequences. The alternative scoring procedure involved calculating memory span and sequencing span. An individual's memory span was calculated by determining the longest 
Table 2. Mean (and standard deviation) of the 189 children using the original memory and sequencing scoring given by Yathiraj and Vijayalakshmi (2006), across age groups, for four lists having varying inter-stimulus intervals (ISIs)

\begin{tabular}{|c|c|c|c|c|c|c|c|c|c|c|c|c|c|c|c|}
\hline \multirow{3}{*}{$\begin{array}{l}\begin{array}{c}\text { Age } \\
\text { group }\end{array} \\
5 \text { years }\end{array}$} & \multirow{3}{*}{$\begin{array}{l}\boldsymbol{N} \\
27\end{array}$} & \multicolumn{3}{|c|}{$\begin{array}{c}\text { List I } \\
\text { (ISI=250 ms) }\end{array}$} & \multicolumn{4}{|c|}{$\begin{array}{c}\text { List II } \\
\text { (ISI=500 ms) }\end{array}$} & \multicolumn{4}{|c|}{$\begin{array}{c}\text { List III } \\
\text { (ISI=750 ms) }\end{array}$} & \multicolumn{3}{|c|}{$\begin{array}{l}\text { List IV } \\
\text { (ISI=1 s) }\end{array}$} \\
\hline & & \multicolumn{2}{|c|}{$\begin{array}{l}\text { Mean (SD) } \\
\text { memory } \\
\text { score }\end{array}$} & $\begin{array}{l}\text { Mean (SD) } \\
\text { sequencing } \\
\text { score }\end{array}$ & \multicolumn{2}{|c|}{$\begin{array}{c}\text { Mean (SD) } \\
\text { memory } \\
\text { score }\end{array}$} & \multicolumn{2}{|c|}{$\begin{array}{l}\text { Mean (SD) } \\
\text { sequencing } \\
\text { score }\end{array}$} & \multicolumn{2}{|c|}{$\begin{array}{l}\text { Mean (SD) } \\
\text { memory } \\
\text { score }\end{array}$} & \multicolumn{2}{|c|}{$\begin{array}{l}\text { Mean (SD) } \\
\text { sequencing } \\
\text { score }\end{array}$} & \multicolumn{2}{|c|}{$\begin{array}{l}\text { Mean (SD) } \\
\text { memory } \\
\text { score }\end{array}$} & $\begin{array}{l}\text { Mean (SD) } \\
\text { sequencing } \\
\text { score }\end{array}$ \\
\hline & & 54.66 & $(6.45)$ & $10.26(6.10)$ & 55.11 & (7.27) & 9.78 & (7.03) & 46.00 & $(7.78)$ & 4.85 & $(3.75)$ & 44.59 & (7.47) & $3.18 \quad(2.59)$ \\
\hline 6 years & 26 & 69. & $(8.52)$ & $22.38 \quad(9.07)$ & 68.11 & (7.50) & 19.23 & $(7.45)$ & 6 & (12.15) & 12.04 & (8.99) & 55. & (12.09) & $9.23 \quad(7.14)$ \\
\hline 7 years & 26 & 81.69 & $(3.25)$ & $47.88(10.50)$ & 82.00 & (3.25) & 48.00 & (11.30) & 75.38 & $(3.65)$ & 33.69 & (11.53) & 73.61 & (4.79) & $30.80(12.71)$ \\
\hline 8 years & 27 & 85.74 & $(4.50)$ & $48.74 \quad(8.91)$ & 84.18 & (5.59) & 48.3 & $.96)$ & 79.14 & $(8.08)$ & 36.1 & ) & 78 & (3.93) & 36. \\
\hline 9 years & 27 & 88.74 & (7.31) & $53.78(12.45)$ & 88.59 & (7.56) & 54.96 & $0.94)$ & 82.67 & $(6.89)$ & 44.18 & (11.22) & 80.85 & (7.20) & $44.04(13.46)$ \\
\hline 10 years & 28 & 94.75 & (6.94) & 63.96 (12.59) & 94.25 & (6.05) & 62.57 & (13.38) & 90.75 & $(7.62)$ & 58.28 & (12.68) & 87.89 & (6.58) & $54.50(11.37)$ \\
\hline 11 years & 28 & 102.61 & $(4.50)$ & $75.03 \quad(8.35)$ & 101.85 & (5.91) & 73.50 & (11.75) & 96.60 & $(5.17)$ & 67.28 & $(7.58)$ & 94.07 & $(5.31)$ & $63.10 \quad(8.32)$ \\
\hline
\end{tabular}

Maximum possible score $=118$

Table 3. Mean (and standard deviation) of memory span and sequencing span obtained from each of the four lists having varying inter-stimulus intervals (ISIs), across the seven age groups

\begin{tabular}{|c|c|c|c|c|c|c|c|c|c|}
\hline \multirow{2}{*}{$\begin{array}{l}\text { Age } \\
\text { group }\end{array}$} & \multirow[b]{2}{*}{$N$} & \multicolumn{2}{|c|}{$\begin{array}{c}\text { List I } \\
\text { (ISI=250 ms) }\end{array}$} & \multicolumn{2}{|c|}{$\begin{array}{c}\text { List II } \\
\text { (ISI=500 ms) }\end{array}$} & \multicolumn{2}{|c|}{$\begin{array}{c}\text { List III } \\
\text { (ISI=750 ms) }\end{array}$} & \multicolumn{2}{|c|}{$\begin{array}{l}\text { List IV } \\
(I S \mid=1 \text { s) }\end{array}$} \\
\hline & & $\begin{array}{c}\text { Mean (SD) } \\
\text { memory } \\
\text { span }\end{array}$ & $\begin{array}{c}\text { Mean (SD) } \\
\text { sequencing } \\
\text { span }\end{array}$ & $\begin{array}{c}\text { Mean (SD) } \\
\text { memory } \\
\text { span }\end{array}$ & $\begin{array}{l}\text { Mean (SD) } \\
\text { sequencing } \\
\text { span }\end{array}$ & $\begin{array}{c}\text { Mean (SD) } \\
\text { memory } \\
\text { span }\end{array}$ & $\begin{array}{l}\text { Mean (SD) } \\
\text { sequencing } \\
\text { span }\end{array}$ & $\begin{array}{c}\text { Mean (SD) } \\
\text { memory } \\
\text { span }\end{array}$ & $\begin{array}{l}\text { Mean (SD) } \\
\text { sequencing } \\
\text { span }\end{array}$ \\
\hline 5 years & 27 & 2.62 & $2.07(1.46)$ & $2.48(1.22)$ & $1.33(1.52)$ & 0.89 (1.39) & $0.44(1.09)$ & 0.89 (1.39) & $0.33(0.96)$ \\
\hline 6 years & 26 & $3.46(0.50)$ & $3.15(0.78)$ & $2.61(1.52)$ & $2.15(1.64)$ & 2.15 & $1.54(1.72)$ & $1.88(1.68)$ & $1.00(1.55)$ \\
\hline 7 years & 26 & $3.92(0.39)$ & $3.65(0.48)$ & $3.96(0.19)$ & $3.77(0.43)$ & $3.80(0.40)$ & $3.57(0.50)$ & $3.65(0.84)$ & $3.38(0.85)$ \\
\hline 8 years & 27 & $4.22(0.42)$ & $3.81 \quad(0.48)$ & $4.03(0.51)$ & $3.70(0.46)$ & $3.89(0.50)$ & $3.59(0.50)$ & $3.89(0.32)$ & $3.44(0.5)$ \\
\hline 9 years & 27 & $4.40(0.64)$ & $4.15(0.36)$ & $4.40(0.57)$ & $4.00(0.39)$ & $4.04(0.19)$ & $3.89(0.42)$ & $3.96(0.34)$ & $3.74(0.52)$ \\
\hline 10 years & 28 & $4.78(0.63)$ & $4.14 \quad(0.52)$ & $4.82(0.55)$ & $4.25(0.52)$ & $4.53(0.64)$ & $4.03(0.19)$ & $4.21 \quad(0.42)$ & $3.93(0.26)$ \\
\hline 11 years & 28 & $5.5(0.64)$ & $4.89(0.31)$ & $5.5(0.64)$ & $4.64(0.62)$ & $4.82(0.67)$ & $4.28(0.46)$ & $4.75(0.58)$ & $4.07(0.38)$ \\
\hline
\end{tabular}

Maximum possible span score $=8$

word sequence in which $50 \%$ of the tokens were correctly recalled, irrespective of the sequence. In a similar way, the sequencing span was calculated as the longest word sequence in which $50 \%$ of the tokens were identified in the correct order. Thus, for an individual who recalled 2 out of the 4 tokens in the 5 -word sequence but only 1 of the 4 tokens in the 6-word sequence, the memory span was calculated as 5 . However, for an individual who recalled 1 of the 2 tokens in the 4 -word sequence and 2 of the 4 tokens in the 5-word sequence, the memory span was calculated as 5. Likewise, if 1 of the 2 tokens in the 4 -word sequence and 2 of the 4 tokens in the 5 -word sequences were recalled in the correct sequence also, then the sequencing span was also calculated as 5 .

The original scores and the recalculated scores were analysed using descriptive statistics as well as inferential statistics. The scores obtained from the 189 children using the two scoring procedures (the original memory and sequencing scores vs. the memory and sequencing span) were compared separately for each of the seven age groups as well as for the groups combined. The analyses were carried out using SPSS software (version 18).

\section{Results}

The mean values obtained by the 189 children for the scoring procedure of Yathiraj and Vijayalakshmi [20] are shown in Table 2 and the alternative scoring procedure used in the current study are shown in Table 3. The mean values shown in these tables highlight the variation in performance across age groups using both scoring procedures. Memory, calculated using the original and the current scoring procedures, increased gradually with age. Similarly, both scoring procedures resulted in a decrease in performance with an increase in inter-stimulus interval. List I, with the smallest inter-stimulus interval, resulted in better scores compared to List IV that had the longest interval. Further, since Yathiraj and Vijayalakshmi [20] reported no difference between the scores of lists I and II, 
Table 4. Mean (and standard deviation) for memory span and sequencing span obtained from the seven age groups, with scores for equivalent Lists I and II averaged

\begin{tabular}{cccccc}
\hline $\begin{array}{c}\text { Age } \\
\text { group }\end{array}$ & $\boldsymbol{N}$ & \multicolumn{2}{c}{$\begin{array}{c}\text { Mean (SD) } \\
\text { memory span }\end{array}$} & \multicolumn{3}{c}{$\begin{array}{c}\text { Mean (SD) } \\
\text { sequencing span }\end{array}$} \\
\hline 5 years & 27 & 2.56 & $(1.18)$ & 1.70 & $(1.53)$ \\
\hline 6 years & 26 & 3.04 & $(1.20)$ & 2.65 & $(1.37)$ \\
\hline 7 years & 26 & 3.94 & $(0.30)$ & 3.71 & $(0.46)$ \\
\hline 8 years & 27 & 4.13 & $(0.48)$ & 3.76 & $(0.47)$ \\
\hline 9 years & 27 & 4.41 & $(0.60)$ & 4.07 & $(0.38)$ \\
\hline 10 years & 28 & 4.80 & $(0.58)$ & 4.20 & $(0.52)$ \\
\hline 11 years & 28 & 5.50 & $(0.63)$ & 4.77 & $(0.50)$ \\
\hline Total & $\mathbf{1 8 9}$ & $\mathbf{4 . 0 7}$ & $\mathbf{( 1 . 2 1 )}$ & $\mathbf{3 . 5 7}$ & $\mathbf{( 1 . 2 9 )}$ \\
\hline
\end{tabular}

the responses of these two lists were averaged for each age groups. The steady increase with age continues to be evident when the span scores of the two lists are averaged, as can be seen in Table 4 and Figure 1. The mean memory span was always better than the mean sequencing span. This was apparent for each age group as well as when the seven age groups were combined (Table 4).

Pearson's correlation coefficient was calculated to examine the correlation between the scores obtained using the original (memory and sequencing score) and the alternative scoring procedures (memory and sequencing span). The results of the correlation for the seven age groups, for each of the four lists, are given in Table 5. From Table 5 it is evident that, for the four lists, significant correlations are present between memory score and memory span, as well as between sequencing score and sequencing span. Although significant moderate to high correlations were present for most age groups, it was absent for some. The restricted standard deviations present for several of the age groups (Table 3 ) could have influenced

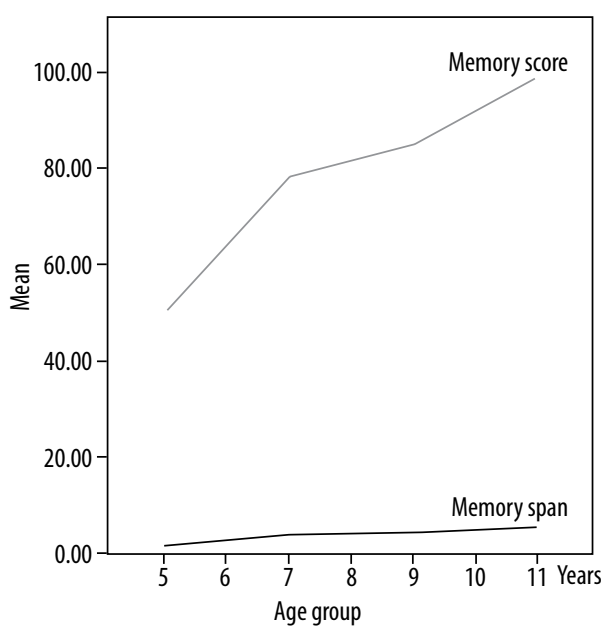

the value of $r$ (Pearson's correlation coefficient), leading to poor correlations. Comrey and Lee (28) have reported that when the variability in scores is limited or truncated, the resulting correlation is reduced. This is also supported by Goodwin and Leech [29] who noted that $r$-values are higher if the variability is more. This occurs since in the formula for calculation of correlation coefficient the covariance is divided by the product of the standard deviations of the two variables. Hence, a smaller variance in the sample will lead to a smaller value of $r$. Similarly, a higher variability in the sample, indicated by a higher covariance value, will result in a higher $r$ value. Thus, in order to increase the variability in the data in the current study, the responses of the seven age groups were combined for each list (Table 6). With the responses combined for the seven age groups, high positive correlations, that were highly significant, were found between the memory score and the memory span as well as the sequencing score and sequencing span (Table 6).

ANOVA was carried out to study the effect of age on memory span and sequencing span. A significant effect of age on memory $\operatorname{span}(F(6,371)=91.35, p<.001)$ and sequencing $\operatorname{span}(F(6,371)=77.99, p<.001)$ was found. To determine the age groups that differed from each other, pair-wise comparisons (after Bonferroni correction) were carried out. The results revealed that, in terms of memory span, a significant difference occurred between all age groups except children aged 7 to 9 years. These children aged 7,8 , and 9 years did not differ from their adjacent older age groups (Table 7). Similarly, on the sequencing span there were no significant differences in performance from the age of 7 until 10 years (Table 8). The youngest two age groups (5 and 6 year olds) were significantly different from the other age groups. Likewise, the oldest age group (11 year olds) performed significantly better than most of the younger age groups. This trend in performance of the youngest two and the oldest age groups was similar for the memory span (Table 7) and the sequencing span (Table 8).

Thus, the findings of the study indicate that there was a significantly high correlation between the two scoring

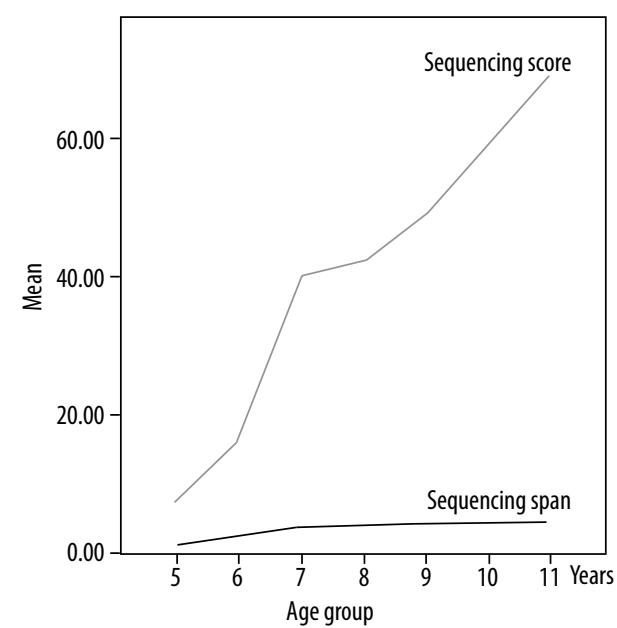

Figure 1. (A) Comparison of mean memory score (top) and memory span (bottom) for the seven age groups. (B) Sequencing score (top) and sequencing span (bottom) for the seven age groups, with scores from Lists I and II averaged 
Table 5. Correlation between memory score and memory span as well as sequencing score and sequencing span for each of the age groups, across the four lists

\begin{tabular}{|c|c|c|c|c|c|c|c|c|c|}
\hline \multirow[b]{2}{*}{$\begin{array}{l}\text { Age } \\
\text { group }\end{array}$} & \multirow[b]{2}{*}{$N$} & \multicolumn{2}{|c|}{ List I } & \multicolumn{2}{|c|}{ List II } & \multicolumn{2}{|c|}{ List III } & \multicolumn{2}{|c|}{ List IV } \\
\hline & & $\begin{array}{l}\text { Memory } \\
\text { span and } \\
\text { memory } \\
\text { score }\end{array}$ & $\begin{array}{l}\text { Sequencing } \\
\text { span and } \\
\text { sequencing } \\
\text { score }\end{array}$ & $\begin{array}{l}\text { Memory } \\
\text { span and } \\
\text { memory } \\
\text { score }\end{array}$ & $\begin{array}{l}\text { Sequencing } \\
\text { span and } \\
\text { sequencing } \\
\text { score }\end{array}$ & $\begin{array}{l}\text { Memory } \\
\text { span and } \\
\text { memory } \\
\text { score }\end{array}$ & $\begin{array}{l}\text { Sequencing } \\
\text { span and } \\
\text { sequencing } \\
\text { score }\end{array}$ & $\begin{array}{l}\text { Memory } \\
\text { span and } \\
\text { memory } \\
\text { score }\end{array}$ & $\begin{array}{l}\text { Sequencing } \\
\text { span and } \\
\text { sequencing } \\
\text { score }\end{array}$ \\
\hline 5 years & 27 & 0.1 & 0.2 & $0.51^{\star \star}$ & $0.53^{* *}$ & $0.40^{*}$ & $0.52^{\star *}$ & $0.58^{\star *}$ & $0.58^{\star \star}$ \\
\hline 6 years & 26 & $0.72^{\star * \star}$ & 0.36 & $0.68^{\star \star \star}$ & $0.39^{\star}$ & $0.68^{* * *}$ & $0.62^{\star \star}$ & $0.84^{\star * *}$ & $0.81^{\star \star *}$ \\
\hline 7 years & 26 & -0.21 & -0.2 & 0.38 & $0.51^{* *}$ & $0.43^{*}$ & $0.56^{\star *}$ & $0.58^{\star *}$ & $0.52^{* *}$ \\
\hline 8 years & 27 & -0.02 & -0.27 & $0.72^{\star \star \star}$ & 0.311 & 0.31 & $0.43^{*}$ & $0.57^{\star *}$ & $0.51^{\star *}$ \\
\hline 9 years & 27 & 0.36 & $0.39^{*}$ & $0.66^{\star * *}$ & $0.71^{\star \star \star *}$ & 0.36 & 0.23 & $0.52^{\star *}$ & $0.6^{* *}$ \\
\hline 10 years & 28 & $0.55^{\star \star}$ & 0.21 & $0.65^{\star \star \star}$ & $0.66^{\star \star \star}$ & $0.75^{\star \star \star}$ & 0.25 & $0.45^{\star}$ & 0.0 \\
\hline 11 years & 28 & $0.6^{\star \star}$ & 0.27 & $0.75^{\star \star \star}$ & $0.63^{* \star \star}$ & $0.53^{\star *}$ & 0.02 & $0.58^{\star \star}$ & 0.19 \\
\hline
\end{tabular}

Table 6. Correlation between memory score and memory span as well as sequencing score and sequencing span for the 7 age groups combined, for each of the four lists

\begin{tabular}{cccccccc}
\hline \multicolumn{2}{c}{ List I } & \multicolumn{2}{c}{ List II } & \multicolumn{2}{c}{ List III } & List IV \\
\hline $\begin{array}{c}\text { Memory } \\
\text { span and } \\
\text { memory score }\end{array}$ & $\begin{array}{c}\text { Sequencing } \\
\text { span and } \\
\text { sequencing } \\
\text { score }\end{array}$ & $\begin{array}{c}\text { Memory } \\
\text { span and } \\
\text { memory score }\end{array}$ & $\begin{array}{c}\text { Sequencing } \\
\text { span and } \\
\text { sequencing } \\
\text { score }\end{array}$ & $\begin{array}{c}\text { Memory } \\
\text { span and } \\
\text { memory score }\end{array}$ & $\begin{array}{c}\text { Sequencing } \\
\text { span and } \\
\text { sequencing } \\
\text { score }\end{array}$ & $\begin{array}{c}\text { Memory } \\
\text { span and } \\
\text { memory score }\end{array}$ & $\begin{array}{c}\text { Sequencing } \\
\text { span and } \\
\text { sequencing } \\
\text { score }\end{array}$ \\
\hline $0.8^{*}$ & $0.7^{*}$ & $0.84^{*}$ & $0.79^{*}$ & $0.86^{*}$ & $0.78^{*}$ & $0.89^{*}$ & $0.82^{*}$ \\
\hline${ }^{*} p<.001$ & & & & & &
\end{tabular}

Table 7. Comparison across age groups on memory span

\begin{tabular}{|c|c|c|c|c|c|c|}
\hline Age group & 5 years & 6 years & 7 years & 8 years & 9 years & 10 years \\
\hline 6 years & * & & & & & \\
\hline 7 years & $* * *$ & $* * *$ & & & & \\
\hline 8 years & $* \star \star$ & $* * \star$ & NS & & & \\
\hline 9 years & $* * *$ & $* * *$ & * & NS & & \\
\hline 10 years & $* * *$ & $* * *$ & $* * *$ & $* * *$ & NS & \\
\hline 11 years & $\star \star \star$ & $* * \star$ & $\star * *$ & $\star \star \star$ & $* * \star$ & $* \star *$ \\
\hline
\end{tabular}

${ }^{\star} p<0.05 ;{ }^{* * *} p<0.001$; NS - not significantly different

procedures evaluated. The significant interaction between age and the span scores indicates that the different age groups do not function in a similar manner. With increase in age, a gradual increase in span scores was observed.

\section{Discussion}

The current study compared two scoring procedures for evaluating auditory memory, one originally used by Yathiraj and
Vijayalakshmi [20] and an alternative procedure used in the current study. While the original procedure calculated auditory memory and sequencing scores, the alternative procedure calculated auditory memory and sequencing span.

Both scoring procedures, the original and the alternative, showed gradual improvement with increasing age. This is evident from the slope of the graphs depicted in Figure $1 \mathrm{a}, \mathrm{b}$ and from the information in Tables 2 and 3. However, 
Table 8. Comparison across age groups on sequencing span

\begin{tabular}{|c|c|c|c|c|c|c|}
\hline Age group & 5 years & 6 years & 7 years & 8 years & 9 years & 10 years \\
\hline 6 years & $* * *$ & & & & & \\
\hline 7 years & $* * *$ & $* * *$ & & & & \\
\hline 8 years & $* * *$ & $* * *$ & NS & & & \\
\hline 9 years & $* * *$ & $* * *$ & NS & NS & & \\
\hline 10 years & $\star * *$ & $* * *$ & NS & NS & NS & \\
\hline 11 years & $* * *$ & $* * *$ & $* * *$ & $* * *$ & $* *$ & * \\
\hline
\end{tabular}

the slope was greater for the original scoring procedure (memory and sequencing score) compared to the procedure currently used (memory and sequencing span). While the original scoring procedure was reported by Yathiraj and Vijayalakshmi [20] to improve significantly across all age groups, the memory span and sequencing span only increased marginally after the age of 7 years. This marginal improvement in auditory memory and sequencing span with age is corroborated by the lack of a significant difference between the adjacent age groups after 7 years. The span increased markedly only in the oldest age group that was studied ( 11 year olds). The above pattern of responses for the two scoring procedures was maintained irrespective of the list that was evaluated.

The results are in consensus with those reported by Huttenlocher and Burke [30], Gathercole et al. [31], and Alloway et al. [32]. Alloway et al. [32] noted the improvement in verbal short-term memory capacity for words, digits, and non-words in children from 4 years to 11 years. They also reported that memory levelled off between 10 and 11 years. Similarly, Gathercole et al. [31] reported an improvement with age in children aged 4 years to 15 years for a variety of verbal stimuli. However, they noted that memory ability levelled off between 14 and 15 years. Likewise, Huttenlocher and Burke [30] reported an improvement with age in the ability of children aged $4,7,9$, and 11 years to recall digits presented by speech.

Similar to the behavioural age-related changes in memory span, Howard and Polich [33] observed that improvement in digit span with age was linked with event-related brain potentials. They reported a decrease in the latency of P300 as digit span increased. They also observed that the span increased with age in children aged 5 to 14 years. They attributed the decrease in P300 latency to an age-related improvement in stimulus processing abilities. From their findings, it can be inferred that age-related improvements in memory abilities depend on maturational changes in cortical areas responsible for generating P300. Studies aimed at locating the sources of the $\mathrm{P} 300$ potential have reported multiple possible generators, one of them being the hippocampus [34-36]. Further, Ellis [37] and Isaacson and Pribram [38] have reported that the hippocampus and amygdala in the anterior temporal regions are associated with memory. These studies suggest that the cortical areas responsible for memory and some P300 generators are similar. Hence, maturation of these common areas might be responsible for improved memory abilities.
It is possible that improved performance with age depends not only on development of memory but also on the maturation of other skills as well. As the participants in the current study were required to give oral responses, it is possible that maturation of perception and speech production had an effect. Henry and Millar [39] concluded that a single factor could not be responsible for the improvement in memory span with age. They opined that identification time and articulation time were factors that helped in the development of improved memory span.

Additionally, in the present study memory span was always better than sequencing span in all seven age groups. This was similar to the findings of Yathiraj and Vijayalakshmi [20] who reported that memory scores were always higher than sequencing scores. These findings reflect the extra difficulty in recalling items in the correct order compared to recalling them in any order. Remembering items in the correct sequence imposes a greater load on memory since it involves recall of two different aspects, the test items and the order in which they occur.

A moderate to high significant correlation was obtained between the two scoring procedures for the four lists across most of the age groups (Table 5). As mentioned earlier, a significant correlation could not be obtained for some age groups due to lack of variability, especially in the span scores. This lack of variability was more obvious for List I, probably because of the ease of the task. The lower interstimulus interval in this list possibly resulted in the participants within certain age groups performing in a similar manner. However, when the seven age groups as well as the lists were combined, a high significant correlation was found between the two scoring procedures (Table 6). The significantly high correlation found between the two scoring procedures indicates that the original scoring procedure, which is more tedious, can be replaced by calculating only memory span and sequencing span.

The use of memory span and sequencing span can reduce the time required to evaluate auditory memory and sequencing abilities when using the 'Kannada auditory memory and sequencing test'. The alternative scoring procedure requires only about 4 minutes to complete when testing individuals who have a memory span of 5 (the mean span measured). In comparison, the original scoring procedure required about 10 minutes to complete the test. This means the duration of the test can be approximately halved. Furthermore, the sense of failure and frustration 
that individuals may experience when they are unable to repeat longer word sequences can be avoided. In this way, the alternative scoring procedure would be especially helpful when evaluating those with reduced auditory memory abilities. Nevertheless, if more subtle differences in memory abilities are required, then the original scoring procedure (memory score and sequencing score) is recommended. This recommendation is made in the light of the large difference in performance seen across ages when the original scoring procedure is used, a difference which is absent when span is calculated.

Finally, it is recommended that when calculating auditory memory or sequencing span, testing should not be discontinued at the first instance when $50 \%$ of the tokens are identified correctly. This recommendation is based on the observation that some of the participants continued to recall $50 \%$ of the items at a subsequent level, resulting in them obtaining a higher memory sequencing span. Some $6.8 \%(13 / 189$ participants) recalled $50 \%$ of the tokens at two subsequent levels and $4.7 \%$ (9/189 participants) recalled $50 \%$ of the token at two subsequent levels in the correct sequence. Hence, testing should continue until less than $50 \%$ of the tokens are identified.

\section{References:}

\section{Conclusions}

The current study compared two scoring procedures to evaluate auditory memory abilities. The original procedure calculated auditory memory and sequencing score whereas the alternative procedure calculated auditory memory and sequencing span. Both scoring procedures showed a gradual improvement in memory and sequencing abilities with age. However, the memory score/span was always higher than the sequencing score/span. Furthermore, a significantly high correlation was obtained between the two scoring procedures. This indicates that the alternative scoring procedure used in the current study can be used in place of the original scoring procedure. This has the potential to reduce the total time required to evaluate auditory memory abilities. The use of the alternative scoring procedure may also reduce the sense of failure individuals may experience when they are unable to repeat longer sequences. However, it is recommended that the original scoring procedure be used when more subtle differences in memory abilities across ages are being assessed.

\section{Acknowledgements}

We thank the All India Institute of Speech and Hearing, Mysore, for facilities provided.
1. Adams A-M, Gathercole SE. Phonological working memory and speech production in preschool children. J Speech Lang Hear Res, 1995; 38(2): 403-14.

2. Adams A-M. Phonological working memory and spoken language development in young children. Quarterly Journal of Experimental Psychology Section A, 1996; 49(1): 216-33.

3. Gathercole SE, Service E, Hitch GJ, Adams A-M, Martin AJ. Phonological short-term memory and vocabulary development: further evidence on the nature of the relationship. Applied Cognitive Psychology, 1999; 13(1): 65-77.

4. Goldstein EB. Cognitive Psychology: Connecting mind, research and everyday experience. Second Edition, ed. Belmont, CA: Thomson Wadsworth; 2008.

5. Muthuselvi T, Yathiraj A. Utility of the screening checklist for auditory processing (SCAP) in detecting (C)APD in children. Student research at AIISH, Mysore (article based on dissertation done at AIISH), 2009; 7: 159-75.

6. Yathiraj A, Maggu AR. Screening Test for Auditory Processing (STAP): a preliminary report. J Am Acad Audiol, 2013;24(9): $867-78$.

7. Alloway TP, Gathercole SE, Adams AM, Willis C, Eaglen R, Lamont E. Working memory and phonological awareness as predictors of progress towards early learning goals at school entry. Brit J Dev Psychol, 2005; 23(3): 417-26.

8. Daneman M, Carpenter PA. Individual differences in working memory and reading. J Verb Learn Verb Beh, 1980;19(4): $450-66$.

9. Gathercol SE, Pickering SJ. Working memory deficits in children with low achievements in the national curriculum at 7 years of age. Br J Educ Psychol, 2000; 70: 177-94.

10. Gathercole S, Pickering S. Working memory deficits in children with special educational needs. British Journal of Special Education, 2001;28(2): 89-97.
11. Gathercole SE, Brown L, Pickering SJ. Working memory assessments at school entry as longitudinal predictors of national curriculum attainment levels. Educational and Child Psychology, 2003; 20(3): 109-22.

12. Schweizer $\mathrm{K}$, Moosbrugger $\mathrm{H}$. Attention and working memory as predictors of intelligence. Intelligence, 2004; 32(4): 329-47.

13. Siegel LS, Linder BA. Short-term memory processes in children with reading and arithmetic learning disabilities. Dev Psychol, 1984; 20(2): 200-7.

14. Swanson HL. Working memory in learning disability subgroups. J Exp Child Psychol, 1993;56(1): 87-114.

15. Carlesimo GA, Marotta L, Vicari S. Long-term memory in mental retardation: evidence for a specific impairment in subjects with Down's syndrome. Neuropsychologia, 1997; 35(1): 71-9.

16. Yathiraj A, Vanaja CS, Muthuselvi T. Maturation of Auditory Processes in Children Aged 6 to 10 Years. Mysore: All India Institute of Speech and Hearing; 2010. http://203.129.241.86: 8080/digitallibrary/AuthorTitle.do?jAuthor $=$ Asha\%20 Yathiraj\%20and\%20Vanaja,\%20C.\%20S.

17. Yathiraj A, Maggu AR. Screening Test for Auditory Processing (STAP): revelations from principal component analysis. SSW Reports, 2012; 34(3): 16-24.

18. Pickering SJ, Gathercole SE. Working Memory Test Battery for Children. London: Psychological Corp; 2001.

19. Alloway TP. The Automated Working Memory Assessment. London: Pearson Assessment; 2007.

20. Yathiraj A, Vijayalakshmi CS. Kannada Auditory Memory and Sequencing Test. Mysore: All India Institute of Speech and Hearing; 2006. http://203.129.241.86:8080/digitallibrary/AuthorTitle.do?jAuthor=Asha\%20Yathiraj;\%20Vijayalakshmi,\%20 C.S.

21. Anderson VA. Auditory memory span as tested by speech sounds. Am J Psychol, 1939; 52(1): 95-9. 
22. Wepman JM, Morency A. Auditory Memory Span Test. Language Research Assoc.; 1973.

23. Wechsler D. Wechsler Intelligence Scale for Children - Fourth Edition. San Antonio, TX, Pearson; 2003.

24. Wechsler D. Wechsler Adult Intelligence Scale - Fourth Edition. San Antonio, TX, Pearson; 2008.

25. Conway AR, Kane MJ, Bunting MF, Hambrick DZ, Wilhelm O, Engle RW. Working memory span tasks: A methodological review and user's guide. Psychon Bull Rev, 2005; 12(5): 769-86.

26. Yathiraj A, Mascarenhas K. Effect of Auditory Stimulation in Central Auditory Processing in Children with CAPD. Mysore: All India Institute of Speech and Hearing; 2003. http://203.129.241.86: 8080/digitallibrary/AuthorTitle. do?jAuthor=Asha\%20Yathiraj;Kavita,\%20EM.

27. Yathiraj A, Mascarenhas K. Auditory profile of children with suspected auditory processing disorder. Journal of Indian Speech and Hearing Association, 2004; 18: 6-14.

28. Comrey AL, Lee HB. Elementary Statistics: A Problem Solving Approach. 4 ed. Morrisville, NC: Lulu.Com; 2007.

29. Goodwin LD, Leech NL. Understanding correlation: factors that affect the size of $r$. Journal of Experimental Education, 2006; 74(3): 249-66.

30. Huttenlocher J, Burke D. Why does memory span increase with age? Cognit Psychol, 1976; 8(1): 1-31.
31. Gathercole SE, Pickering SJ, Ambridge B, Wearing H. The structure of working memory from 4 to 15 years of age. Dev Psychol, 2004; 40(2): 177-90.

32. Alloway TP, Gathercole SE, Pickering SJ. Verbal and visuospatial short-term and working memory in children: are they separable? Child Dev, 2006; 77(6): 1698-716.

33. Howard L, Polich J. P300 latency and memory span development. Dev Psychol, 1985; 21(2): 283-9.

34. Smith ME, Halgren E, Sokolik M, Baudena P, Musolino A, Liegeois-Chauvel $\mathrm{C}$ et al. The intracranial topography of the P3 event-related potential elicited during auditory oddball. Electroencephalogr Clin Neurophysiol, 1990; 76(3): 235-48.

35. Halgren E, Baudena P, Clarke JM, Heit G, Liégeois C, Chauvel $\mathrm{P}$ et al. Intracerebral potentials to rare target and distractor auditory and visual stimuli. I. Superior temporal plane and parietal lobe. Electroencephalogr Clin Neurophysiol, 1995; 94(3): 191-220.

36. Halgren E, Marinkovic K, Chauvel P. Generators of the late cognitive potentials in auditory and visual oddball tasks. Electroencephalogr Clin Neurophysiol, 1998; 106(2): 156-64.

37. Ellis M. Amygdala norepinephrine involved in two separate long-term memory retrieval processes. Brain Res, 1985; 342(1): 191-5.

38. Isaacson RL, Pribram KH. The Hippocampus. Plenum Press; 1986.

39. Henry LA, Millar S. Memory span increase with age: A test of two hypotheses. J Exp Child Psychol, 1991;51(3): 459-84. 